\title{
Could moderate earthquakes also trigger cardiac events?
}

\author{
Ana Isabel Ribeiro • Maria de Fátima de Pina
}

Received: 12 October 2012/ Accepted: 5 February 2013/Published online: 14 February 2013

(C) Springer Science+Business Media Dordrecht 2013

The association between cardiac events and the experience of an earthquake has been known for a long time and has been reported in several areas of the world, where significant increases in mortality and morbidity due to acute forms of coronary heart disease (CHD) have been registered $[1,2]$. However, it is not clear why some earthquakes appear to be less harmful than others. It seems that to induce cardiac events, earthquakes must not only reach a relatively high intensity, but also occur at a certain time of day-early morning appears to be the critical day period [3]. Another poorly studied question is whether there are any age and sex differences in excess mortality and morbidity associated with earthquakes, similar to that which occurs for other environmental exposures (e.g. heat waves), whose effect is sharper among older people.

Portugal is among those European countries with the highest seismic risk. In addition, although after the 1755 Lisbon earthquake Portuguese territory has not been

\footnotetext{
A. I. Ribeiro $(\bowtie) \cdot$ M. de Fátima de Pina

GeoEpidemiology Group, INEB, Instituto de Engenharia Biomédica, Universidade do Porto, Rua do Campo Alegre, 823, 4150-180 Porto, Portugal

e-mail: ana.isabel.correia.ribeiro@gmail.com;

ana.isabel.ribeiro@ineb.up.pt

M. de Fátima de Pina

e-mail: fpina@med.up.pt
}

A. I. Ribeiro - M. de Fátima de Pina

GeoEpidemiology Group, Departamento de Epidemiologia Clínica, Medicina Preditiva e Saúde Pública, Faculdade de Medicina, Universidade do Porto, Alameda Prof. Hernâni Monteiro, 4200-319 Porto, Portugal

A. I. Ribeiro · M. de Fátima de Pina ISPUP, Instituto de Saúde Pública da Universidade do Porto, Porto, Portugal affected by such violent quakes, low and moderate magnitude events are very common.

Since the biggest Portuguese earthquake of the twentieth century on 28th February 1969 (8.0 magnitude), which caused 11 deaths due to cardiac disease, only one is known to have caused deaths attributed to heart attack-that of 21st May 1997.

This seism occurred at 11:51 p.m. UTC (0.51 a.m. Portuguese local time) and reached a magnitude of 5.3 and an intensity of VII (MM56 scale) next to the epicentre, in the Northwestern Spanish region of Galicia [4]. Despite its relatively low magnitude, two deaths were caused by cardiac disease triggered by the earthquake.

This study was conducted in order to evaluate whether the 21st May 1997 moderate earthquake was associated with an increase in hospital admissions due to acute myocardial infarction (AMI), usually accompanying high magnitude events.

The 21st May 1997 earthquake was felt not only in Galicia (Spain) but in almost half of Continental Portugal. However, only in the northernmost districts did it reach an intensity of at least IV (MM56 scale), the minimum experienced by the majority of the population and, therefore, capable of triggering any effects in the residents' health. This geographical area comprised 59 municipalities and 1,703,030 residents, who were considered the exposed population (Fig. 1) for the purpose of this study.

Data from the National Hospital Discharge Register (NHDR) was used and admissions with a main diagnosis of AMI, International Codification Diseases 9th revisionClinical Modification (ICD9-CM) codes 410.x were selected.

The time window for investigating the earthquake's effects was chosen according to the following criteria: as the earthquake occurred near midnight of the 21st May 


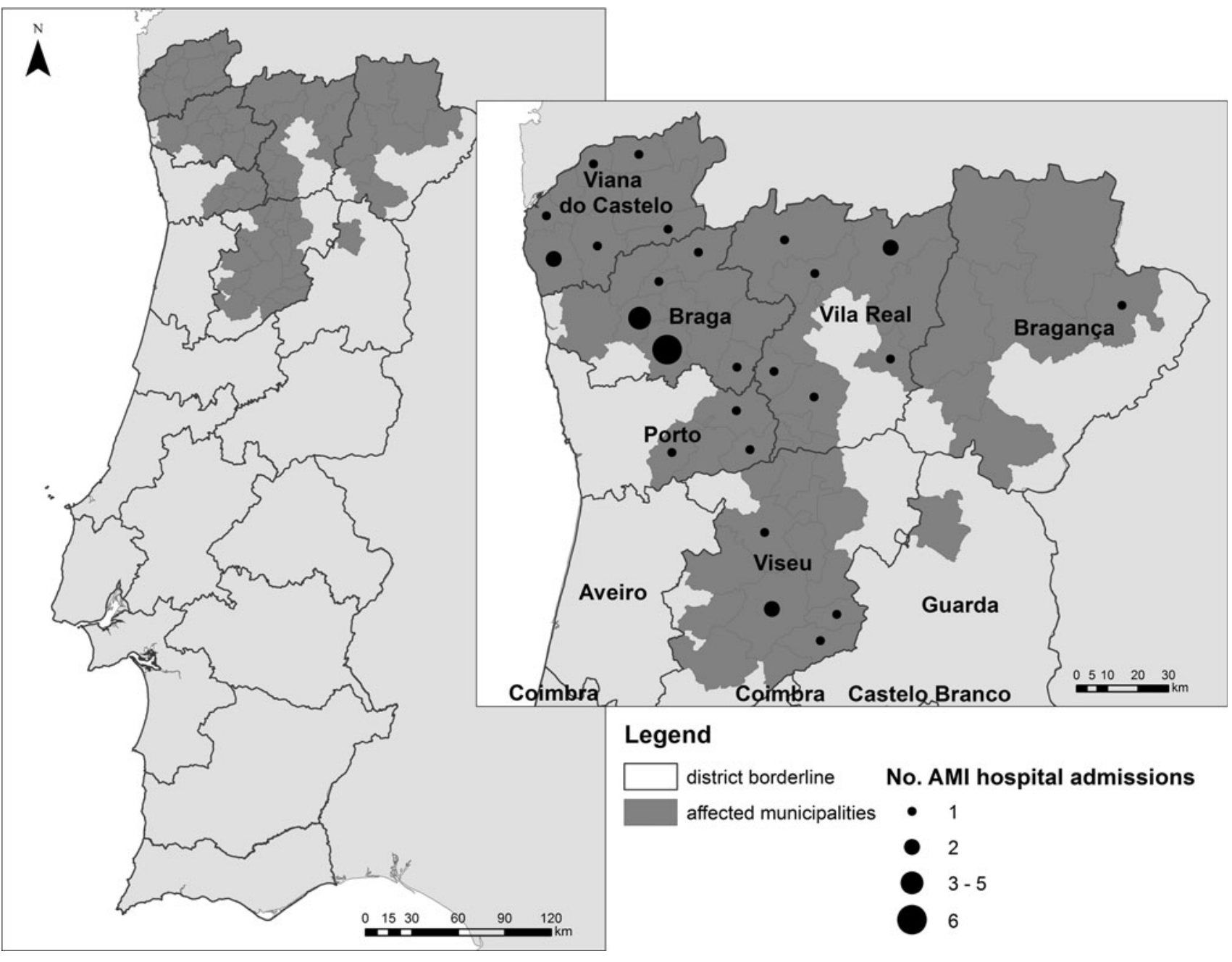

Fig. 1 Geographical area affected by the 21st May 1997 earthquake. Portuguese municipalities where the earthquake reached intensity (MM56) of at least IV and number of hospital admissions by municipality from 22nd to 31st May 1997

1997 and several minor aftershocks were felt in Northern Portugal during the following days, the 10 days between 22nd May (Wednesday) and 31st May (Saturday) were then selected.

We chose as control periods another 10 days before the earthquake time window (8th May to 17th May 1997) and a further 10 days after (5th June to 14th June 1997), plus similar periods in 1998, 1999, 2000 and 2001, in a total of fourteen control periods. To account for the well-known day-of-the-week effect, all periods begin and end on the same week days. Furthermore, to test whether there were sex or age-specific effects, hospital admissions were grouped by sex plus age groups, separating the elderly (65 years old and over) from the remaining patients.

Proportions of hospital admissions for AMI in the affected area (59 municipalities) in relation to the national total number were computed for the 10-day period immediately following the earthquake and for the fourteen control periods. Fisher exact test was used to compare the proportion of national hospital admissions for AMI in the affected area during the exposure and the set of control periods. The same test was employed to explore age and sex differentials. Results were considered significant at a level of 0.05 .

Figure 1 shows the hospital admissions for AMI in the 59 municipalities during the 10-day period after the earthquake and Table 1 shows the proportion of hospital admissions for AMI from the national total number in the 10-day period after the earthquake, plus each control period and the sum of the control periods. The relative number (18.5\%) of national hospital admissions between 22 nd and 31st May 1997 was higher than in any of the fourteen control time windows. A statistically significant difference between the proportion of national hospital admissions after the earthquake and in the total control periods, taken as a whole, was found [18.5\% $95 \%$ CI 13.7-24.5 vs. 
Table 1 Myocardial infarction admissions in the exposure and control periods

\begin{tabular}{lllll}
\hline Period & $\begin{array}{l}\text { No. of } \\
\text { admissions } \\
\text { in the } \\
\text { affected }\end{array}$ & $\begin{array}{l}\text { National } \\
\text { no. of } \\
\text { admissions }\end{array}$ & $\begin{array}{l}\text { Proportion }(\%) \\
\text { of national } \\
\text { admissions in } \\
\text { the affected area } \\
(95 \% \mathrm{CI})\end{array}$ & $\begin{array}{l}p \text { value for } \\
\text { difference }^{\mathrm{b}}\end{array}$ \\
& & & \\
\hline
\end{tabular}

\begin{tabular}{|c|c|c|c|c|}
\hline $\begin{array}{c}8 \text { th-17th } \\
\text { May } \\
1997\end{array}$ & 20 & 202 & $9.9[6.5-14.8]$ & \\
\hline $\begin{array}{l}5 \text { th-14th } \\
\text { June } \\
1997\end{array}$ & 26 & 214 & $12.1[8.4-17.2]$ & \\
\hline $\begin{array}{l}\text { 7th-16th } \\
\text { May1998 }\end{array}$ & 31 & 243 & $12.8[9.1-17.5]$ & \\
\hline $\begin{array}{l}\text { 21st-30th } \\
\text { May } \\
1998\end{array}$ & 23 & 201 & $11.4[7.7-16.6]$ & \\
\hline $\begin{array}{l}\text { 4th-13th } \\
\text { June } \\
1998\end{array}$ & 28 & 248 & $11.3[7.9-15.8]$ & \\
\hline $\begin{array}{l}\text { 6th-15th } \\
\text { May } \\
1999\end{array}$ & 26 & 224 & $11.6[8.0-16.5]$ & \\
\hline $\begin{array}{l}\text { 20th-29th } \\
\text { May } \\
1999\end{array}$ & 30 & 245 & $12.2[8.7-16.9]$ & \\
\hline $\begin{array}{l}\text { 3rd-12th } \\
\text { June } \\
1999\end{array}$ & 23 & 209 & $11.0[7.4-16.0]$ & \\
\hline $\begin{array}{l}\text { 4th-13th } \\
\text { May } \\
2000\end{array}$ & 39 & 256 & 15.2 [11.2-19.9] & \\
\hline $\begin{array}{l}\text { 18th-27th } \\
\text { May } \\
2000\end{array}$ & 23 & 258 & $8.9[6.0-13.0]$ & \\
\hline $\begin{array}{l}\text { 1st-12th } \\
\text { June } \\
2000\end{array}$ & 27 & 227 & 11.9 [8.3-16.8] & \\
\hline $\begin{array}{l}\text { 3rd-12th } \\
\text { May } \\
2001\end{array}$ & 38 & 304 & $12.5[9.2-16.7]$ & \\
\hline $\begin{array}{l}\text { 17th-26th } \\
\text { May } \\
2001\end{array}$ & 38 & 297 & $12.8[9.5-17.1]$ & \\
\hline $\begin{array}{l}\text { 31st May- } \\
\text { 9th June } \\
2001\end{array}$ & 32 & 268 & $11.9[8.6-16.4]$ & \\
\hline $\begin{array}{l}\text { Total } \\
\text { control } \\
\text { periods }\end{array}$ & 404 & 3,396 & $11.9[10.8-13.0]$ & 0.006 \\
\hline $\begin{array}{l}\text { 22nd-31st } \\
\text { May } \\
1997^{\mathrm{a}}\end{array}$ & 37 & 200 & 18.5 [13.7-24.5] & \\
\hline
\end{tabular}

Hospital admissions for myocardial infarction (absolute values in the affected area and nationwide and proportion in the affected area) between 22nd and 31st May 1997 and in the control periods

a Ten-day period after the earthquake

b 22nd-31st May 1997 versus total control periods (Fisher exact test, one-sided)
$11.9 \% 95 \%$ CI $10.8-13.0(p=0.006)]$, which corresponds to a $56 \%$ increase in hospital admissions.

The effect of the earthquake on AMI hospital admissions did not differ by sex or age, globally considered: no statistically significant difference was found in the proportion of female/male or younger/older hospital admissions in the 10-days after the earthquake in comparison with the control period. However, among women, the proportion of patients below 65 years of age was higher between 22nd and 31st May 1997 than in all the control periods $(38.5 \%$ vs. $15.0 \%, p=0.049)$. Statistically significant age differences weren't observed in male patients. Till now, age differences were never found or even studied in the literature, although an increased susceptibility of women to cardiac events after earthquakes has already been reported in previous studies focused on major seismic events [5].

To summarize, a $56 \%$ excess in hospital admissions for AMI was observed after a moderate earthquake, a phenomenon that is quite frequent in many countries in the world. Such findings bring important public health implications: by knowing that even moderate earthquakes could trigger acute coronary events, policy makers should invest in awareness campaigns and educational sessions (at schools and in the community) in order to avoid unnecessary panic situations.

Portugal and other countries are also prone to major earthquakes. Because of this, policy makers, clinicians, emergency personnel should not only be aware of the risk of injuries and damage, but also of a likely substantial increase in cardiovascular events during the days, weeks or even months following a major seism.

Acknowledgments The authors wish to thank Central Administration of the Health System (ACSS) for kindly providing data from the NHDR, indispensable in conducting the present work. This work was supported by FEDER funds through the Programa Operacional Factores de Competitividade-COMPETE and by Portuguese funds through FCT-Fundação para a Ciência e a Tecnologia in the framework of the PEst-C/SAU/LA0002/2011 project and by the SFRH/BD/82529/2011 fellowship.

Conflict of interest The authors declare that they have no conflict of interest.

\section{References}

1. Kario K, McEwen BS, Pickering TG. Disasters and the heart: a review of the effects of earthquake-induced stress on cardiovascular disease. Hypertens Res. 2003;26(5):355-67.

2. Dimsdale JE. Psychological stress and cardiovascular disease. J Am Coll Cardiol. 2008;51(13):1237-46.

3. Brown DL. Disparate effects of the 1989 Loma Prieta and 1994 Northridge earthquakes on hospital admissions for acute myocardial 
infarction: importance of superimposition of triggers. Am Heart J. 1999;137(5):830-6.

4. Rueda J, Mezcua J. Sismicidad, sismotectónica y peligrosidad sísmica en Galicia. Madrid: Instituto Geográfico Nacional; 2001.
5. Kloner RA, Leor J, Poole WK, Perritt R. Population-based analysis of the effect of the Northridge Earthquake on cardiac death in Los Angeles County, California. J Am Coll Cardiol. 1997;30(5): 1174-80. 